\title{
Race is a risk factor for calcinosis in patients with JDM - early results from the CARRAnet registry study
}

\author{
Mark F Hoeltzel ${ }^{1 *}$, Mara L Becker ${ }^{1}$, Angela B Robinson ${ }^{5}$, Brian M Feldman ${ }^{6}$, Adam Huber ${ }^{2}$, Ann M Reed ${ }^{3}$, \\ Juvenile Myositis CARRA Subgroup ${ }^{4}$, CARRAnet Investigators ${ }^{4}$
}

From 2011 Pediatric Rheumatology Symposium sponsored by the American College of Rheumatology Miami, FL, USA. 2-5 June 2011

\section{Purpose}

Previously established risk factors for calcinosis include duration of disease and the length of time to treatment, suggesting early aggressive treatment may be important in preventing calcinosis. Race has also been suggested to be a risk factor, but this observation was thought to be secondary to delays in treatment. We utilized the CARRAnet registry to investigate potential risk factors for calcinosis.

\section{Methods}

Children with juvenile dermatomyositis (JDM) in the Childhood Arthritis and Rheumatology Research Alliance (CARRA) registry study were included in this analysis. Race and ethnicity were self-reported. Subjects with current or past calcinosis were identified, and bi-variable associations between clinical variables and calcinosis were evaluated by Chi-square test, Fisher exact test, two-sample t-test, or Wilcoxon Rank Sum test as appropriate. A multivariable stepwise logistic regression model was run that included variables that were significantly associated in the bi-variable analysis, defined by $P<0.1$. All statistical analyses were conducted using JMP Stats version 8.0 (SAS Institute, Cary, NC).

\section{Results}

Prior to December 28, 2010, 102 subjects meeting modified Bohan and Peter criteria for JDM were enrolled from 23 U.S. sites. Fifteen subjects were excluded due to lack of data regarding calcinosis or race. Ten of the remaining 87 patients had a history of calcinosis. Potential predictors of

${ }^{1}$ Children's Mercy Hospital, Kansas City, MO, USA

Full list of author information is available at the end of the article calcinosis identified a priori included race, ethnicity, sex, ANA status, age, age of onset, duration of disease, and time to rheumatologic care. Bi-variable analyses revealed a significant association between calcinosis and African American (AA) race $(P=0.029)$, disease duration $(P=0.005)$, absence of antinuclear antibodies $(P=0.024)$, and male gen$\operatorname{der}(P=0.037)$ (Table 1$)$. Analyzing these four variables in a multiple stepwise logistic regression model revealed that AA ancestry was the most significant predictor of calcinosis (OR [95\% CI] $5.8[1.3,24.8] P=0.019)$. When demographic variables and outcome assessments were compared between AA patients and non-AA patients, only CHAQ scores were statistically significantly different in AA patients (mean $( \pm$ SD), $0.54( \pm 0.51)$ vs. $0.29( \pm 0.52)$ in non-AA patients $[P=0.033])$.

\section{Conclusion}

Children with JDM of African American ancestry have increased odds of developing calcinosis, even after controlling for duration of disease and time to rheumatologic care. Male gender, negative ANA status, and disease duration were associated with calcinosis in bi-variable analysis, however, these variables were limited by incomplete data capture, which may have affected the results of the multi-variable regression model. Analysis of a larger more complete cohort is needed to confirm these observations.

\section{Disclosure}

Mark F. Hoeltzel: None; Mara L. Becker: None; Angela B. Robinson: None; Brian M. Feldman: None; Adam Huber: None; Ann M. Reed: None; Juvenile Myositis CARRA Subgroup: None; CARRAnet Investigators: None. 
Table 1 Analysis of calcinosis risk factors

\begin{tabular}{llll}
\hline & $\begin{array}{l}\text { Number (\%) or Mean (+/-SD) with } \\
\text { calcinosis }\end{array}$ & $\begin{array}{l}\text { Bi-variable analysis (p- } \\
\text { value) }\end{array}$ & $\begin{array}{l}\text { Stepwise logistic regression analysis (OR [95\%Cl] } p \\
\text { value }\end{array}$ \\
\hline $\begin{array}{l}\text { African American } \\
\text { ancestry }\end{array}$ & $4(33 \%)$ & $0.03^{*}$ & $5.8[1.3,24.8] 0.02^{*}$ \\
Non-AA ancestry & $6(8 \%)$ & & NS \\
Male & $5(26 \%)$ & $0.04^{*}$ & NS \\
Female & $5(7 \%)$ & $0.02^{*}$ & \\
Negative ANA & $6(19 \%)$ & & NS \\
Positive ANA & $1(2 \%)$ & $<0.01^{*}$ & \\
Disease duration, yrs & $7.2(+/-4.1)$ &
\end{tabular}

\section{Author details}

${ }^{1}$ Children's Mercy Hospital, Kansas City, MO, USA. ${ }^{2}$ IWK Health Centre, Halifax,

NS, Canada. ${ }^{3}$ Mayo Clinic, Rochester, MN, USA. ${ }^{4}$ Rainbow Babies and

Childrens Hospital, Cleveland, OH, USA. ${ }^{5}$ The Hospital for Sick Children,

Toronto, ON, Canada. ${ }^{6}$ Stanford, CA, USA.

Published: 13 July 2012

doi:10.1186/1546-0096-10-S1-A65

Cite this article as: Hoeltzel et al: Race is a risk factor for calcinosis in

patients with JDM - early results from the CARRAnet registry study.

Pediatric Rheumatology 2012 10(Suppl 1):A65.

Submit your next manuscript to BioMed Central and take full advantage of:

- Convenient online submission

- Thorough peer review

- No space constraints or color figure charges

- Immediate publication on acceptance

- Inclusion in PubMed, CAS, Scopus and Google Scholar

- Research which is freely available for redistribution

Submit your manuscript at www.biomedcentral.com/submit
C Biomed Central 